\title{
Thymosin beta 4 mRNA and peptide expression in phagocytic cells of different mouse tissues
}

\author{
Melissa Paulussen ${ }^{\mathrm{a}}$, Bart Landuyt ${ }^{\mathrm{b}}$, Liliane Schoofs ${ }^{\mathrm{b}}$, Walter Luyten ${ }^{\mathrm{c}}$, Lut Arckens ${ }^{\mathrm{a}, *}$ \\ a Laboratory of Neuroplasticity and Neuroproteomics, Katholieke Universiteit Leuven, Naamsestraat 59, B-3000 Leuven, Belgium \\ ${ }^{\mathrm{b}}$ Laboratory of Functional Genomics and Proteomics, Katholieke Universiteit Leuven, Naamsestraat 59, 3000 Leuven, Belgium \\ ${ }^{\mathrm{c}}$ Basic Research in Gynaecology, Department of Woman and Child, Biomedical Sciences Group, Katholieke Universiteit Leuven, Herestraat 49, 3000 Leuven, Belgium
}

\section{A R T I C L E IN F O}

\section{Article history:}

Received 7 April 2009

Received in revised form 15 July 2009

Accepted 15 July 2009

Available online xxx

\section{Keywords:}

Thymosin beta 4

Macrophage

Microglia

In situ hybridization

Immunocytochemistry

\begin{abstract}
A B S T R A C T
Thymosin beta 4 (Tß3) is a peptide of 43 amino acids, mainly recognized as a regulator of actin polymerization by sequestering G-actin. Meanwhile, the peptide has been implicated in lymphocyte maturation, carcinogenesis, apoptosis, angiogenesis, blood coagulation and wound healing. The peptide is also involved in lesion-induced neuroplasticity through microglia upregulation and it participates in the growth of neuronal processes. However, its precise cellular localization throughout the entire body of the mouse has not been documented. We therefore initiated a detailed investigation of the tissue distribution and cellular expression of the T $\beta 4$ peptide and its precursor mRNA by immunocytochemistry and in situ hybridization, respectively. In the brain, $\mathrm{T} \beta 4$ was clearly present in neurons of the olfactory bulb, neocortex, hippocampus, striatum, amygdala, piriform cortex and cerebellum, and in microglia across the entire brain. We further localized T 34 in cells, typically with many processes, inside thymus, spleen, lung, kidney, liver, adrenal gland, stomach and intestine. Remarkably, T $\beta 4$ was thus associated with microglia and macrophages, the differentiated phagocytic cells residing in every tissue. Motility and phagocytosis, two important activities of macrophages, depend on actin, which can explain the presence of $\mathrm{T} \beta 4$ in these cells.
\end{abstract}

(c) 2009 Elsevier Inc. All rights reserved.

\section{Introduction}

Thymosin beta 4 (T $\beta 4$ ), a peptide of 43 amino acids, was discovered by extraction from calf thymus and sequenced in the early eighties. It is part of thymosin fraction 5 , a partially purified thymic preparation that participates in thymus-dependent lymphocyte regulation $[42,43]$. The $\beta$-thymosin family is distinguished from the $\alpha$-and $\gamma$-thymosin family by its isoelectric point, which is located between $\mathrm{pH} 5.0$ and 7.0 [20]. T $\beta 4$ is the most prominent member of the $\beta$-thymosin family $[1,28,43]$. It is well conserved during evolution and expressed widely throughout the vertebrate phylum, including fish and amphibia [18].

The first function ascribed to T $\beta 4$ was an immunological one: control of thymus-dependent lymphocyte maturation [43]. Later it was discovered that it mainly functions as an actin-sequestering peptide [53]. T $\beta 4$ forms a 1:1 complex with actin monomers and

\footnotetext{
* Corresponding author. Tel.: +32 16 323951; fax: +32 16324263.

E-mail addresses: melissa.paulussen@bio.kuleuven.be (M. Paulussen), bart.landuyt@bio.kuleuven.be (B. Landuyt), liliane.schoofs@bio.kuleuven.be (L Schoofs), walter.luyten@med.kuleuven.be (W. Luyten), Lut.Arckens@bio.kuleuven.be (L. Arckens).
}

thus inhibits polymerization. The polymerization and depolymerization of actin is essential for a variety of cellular processes, like cell migration, chemotaxis, maintenance of cell shape and cell division $[4,14,53]$. Associated with its role in actin polymerization, $\mathrm{T} \beta 4$ has a variety of other functions [56]. T $\beta 4$ promotes angiogenesis $[26,27,56]$ and in this way enhances wound healing $[44,56]$. It is involved in tumor metastasis; in its presence tumors are larger, with more cell migration and an increase in blood vessel formation [10]. Furthermore, T $\beta 4$ has anti-apoptotic activity, which is independent of its actin-sequestering activity [11], and it plays a role during brain development $[1,8]$. After brain lesions such as deafferentiation of the entorhinal cortex, ischemia or kainate treatment, T $\beta 4$ is upregulated in microglia [7,17,39,62]. Likewise, Yoshida et al. found an upregulation in the kidney in an ischemia-reperfusion model [67]. In the brain, T $\beta 4$ has a neuroprotective effect [48] and it participates in remodeling of neuronal processes and in synaptogenesis $[1,7,22]$.

The presence of T $\beta 4$ in the brain is now well established $[7,23,28,62]$. Reverse-phase high performance liquid chromatography and Northern blot revealed significant quantities of T $\beta 4$ and its mRNA in rat brain $[23,28]$. Carpintero et al. found $T \beta 4$ mRNA in the rat hippocampus, dentate gyrus, neocortex, piriform cortex, entorhinal cortex, amygdala, supraoptic nucleus, premammilary

0196-9781/\$ - see front matter (c) 2009 Elsevier Inc. All rights reserved. doi:10.1016/j.peptides.2009.07.010 
dorsal nucleus, substantia nigra and infundibulum [7]. In addition, Vartiainen et al. localized T $\beta 4$ mRNA in the hippocampus, dentate gyrus, neocortex, piriform cortex, supraoptic nucleus, cingulate cortex, striatum and thalamus in rat brain [62].

$\mathrm{T} \beta 4$ is also known to be present in a variety of other organs, like spleen, thymus, lung, ovary, kidney, intestine, heart, liver and testis $[23,28]$. Based on reverse-phase HPLC, Xu et al. concluded that T $\beta 4$ is synthesized by peritoneal macrophages and spleen cells [65]. Other authors also pointed out the relation between $\mathrm{T} \beta 4$ and macrophages $[24,28,65]$ or microglia $[1,7,17,54,62]$. However, so far research on the visualization of T $\beta 4$ at the peptide level in normal mouse tissues is limited. We therefore conducted a detailed distribution analysis of $\mathrm{T} \beta 4$ both at the transcript and peptide level throughout the entire mouse body and compared it to the macrophage markers CD11b and CD68.

\section{Materials and methods}

\subsection{Animals and tissue preparation}

Adult male mice (age 3 months and up) from the inbred strain C57Bl/6J were obtained from Janvier Elevage (Le Genest-St-Isle, France) and housed under standard laboratory conditions. They were raised in an 11/13 h dark/light cycle with food and water ad libitum. All experiments have been approved by the Institutional Laboratory Animal Use and Care Committee (Animal Facilities, K.U. Leuven, Belgium) and were conducted in strict accordance to the European Communities Council Directive of November 24th 1986 (86/609/EEC).

For in situ hybridization, animals $(n=3)$ were sacrificed by cervical dislocation. The brains and parts of the different organs were rapidly removed and immediately frozen in 2-methylbutane (Merck, Overijse, Belgium) at a temperature of $-40{ }^{\circ} \mathrm{C}$ and stored at $-70{ }^{\circ} \mathrm{C}$ until sectioning. Twenty-five-micron thick sections were prepared on a cryostat (Microm HM 500 OM, Walldorf, Germany), mounted on $0.1 \%$ poly-L-lysine (Sigma-Aldrich, St. Louis, MO)coated slides and stored at $-20^{\circ} \mathrm{C}$ until further processing.

For immunocytochemistry of brain, liver, kidney and spleen, animals $(n=4)$ were sacrificed with an overdose of sodium pentobarbital $(60 \mathrm{mg} / \mathrm{ml}$, i.p.; CEVA Santé Animale, Brussels, Belgium) and immediately perfused transcardially with $1 \%$ paraformaldehyde (Sigma-Aldrich, St. Louis, MO), followed by 4\% paraformaldehyde in $0.15 \mathrm{M}$ sodium phosphate-buffered saline (PBS, pH 7.42). Brains and parts of the different organs were then postfixed in the same fixative for $24 \mathrm{~h}$, rinsed three times with tap water and stored in PBS at $4{ }^{\circ} \mathrm{C}$. Fifty-micron thick sections were cut with a Vibratome (Leica, Leitz instruments, Heidelberg, Germany) and kept as free-floating sections in PBS at $4{ }^{\circ} \mathrm{C}$.

Immunocytochemistry of stomach, intestine, thymus, adrenal gland and lung was done on 25 micron thick cryostat sections $(n=3)$. These sections were prepared in the same way as for in situ hybridization.

\subsection{In situ hybridization}

$\mathrm{T} \beta 4$ in situ hybridization was performed with a synthetic oligonucleotide probe with sequence $5^{\prime}$-agccatatcgggtttgtcagacatggttgctggaaggagccgagcgag-3' (Eurogentec, Seraing, Belgium). As described earlier [2,12], the probe was $3^{\prime}$-end labeled with ${ }^{33} \mathrm{P}$ dATP using terminal deoxynucleotidyl transferase (Invitrogen, Merelbeke, Belgium). Unincorporated nucleotides were separated from the labeled probe with miniQuick SpinTM Oligo Columns (Roche Diagnostics, Brussels, Belgium). Series of cryostat sections were fixated, dehydrated and delipidated. The radioactively labeled probe was added to a hybridization cocktail (50\% formamide, $4 \times$ standard saline sodium citrate buffer, $1 \times$
Denhardt's solution, $1 \%$ sarcosyl N-lauroyl sarcosine sodium salt, $20 \mathrm{mM} \mathrm{NaHPO}_{4} \mathrm{pH} 7.4,10 \%$ dextran sulphate, $100 \mu \mathrm{g} / \mathrm{ml}$ salmon sperm DNA, $250 \mu \mathrm{g} / \mathrm{ml}$ tRNA) and applied to the cryostat sections $\left(10^{6}\right.$ counts per section) for an overnight incubation at $37^{\circ} \mathrm{C}$ in a humid chamber. The following day, sections were rinsed in $1 \times$ standard saline sodium citrate buffer at a temperature of $42{ }^{\circ} \mathrm{C}$, dried and exposed to an autoradiographic film (Kodak, Zaventem, Belgium) for 10 days. Afterwards the films were developed in Kodak D19 developing solution and fixed in Rapid fixer (Ilford Hypam, Kodak). For image production from the autoradiograms, bright field images were captured with a digital Olympus SP-550 UZ camera (Olympus Belgium N.V., Belgium).

As a control, the complementary sense probe was used under identical conditions. No signal was detected for this sense probe (data not shown).

\subsection{Immunocytochemistry}

Immunocytochemistry was performed as described earlier $[59,60]$ with a primary polyclonal rabbit antiserum against $\mathrm{T} \beta 4$ (9520, aa 1-14, immundiagnostik AG, Bensheim). Series of vibratome sections were stained free-floating, while series of cryostat sections were stained on glass slides in humid chambers upon fixation with $4 \%$ paraformaldehyde $\left(30^{\prime}\right)$. All dilutions and rinses were performed with Tris Buffered Saline (TBS, 0.01 M Tris, $0.9 \% \mathrm{NaCl}, 0.3 \%$ Triton-X 100, $\mathrm{pH} 7.6$ ). Sections were pretreated with $0.3 \% \mathrm{H}_{2} \mathrm{O}_{2}$ in TBS, rinsed and preincubated with normal goat serum for $45 \mathrm{~min}$ (1:5, Chemicon, Temecula, CA), followed by overnight incubation at room temperature with primary antiserum (1:8000). The next day, sections were rinsed and incubated for 30 min with biotinylated goat anti-rabbit antibody $\operatorname{IgGs}(1: 500$, Dako, Glostrup, Denmark). Further detection was performed with streptavidin-horseradish peroxidase (1:500, $30 \mathrm{~min}$, Dako, Glostrup, Denmark).

For comparison to a first macrophage marker, the primary monoclonal rat antibody against CD11b, clone 5C6 (MCA711G, AbD Serotec, Oxford, UK) was used, which is directed against an epitope on the alphaM/beta2 integrin complement receptor 3 (CR3). Microglia and macrophages express CR3, which is the same as the macrophage differentiation antigen Mac-1, also named CD11b $[6,38,51]$. As a second macrophage marker, the primary monoclonal rat antibody against CD68 (MCA1957FA, AbD Serotec, Oxford, UK) was used. CD68, macrosialin in the mouse, is known as a classical macrophage marker [13,30-32,49]. For CD11b and CD68 immunocytochemistry, the only modification in the protocol was the detection of the primary antibody (CD11b: 1/8000, CD68: $1 / 2000)$ using biotinylated goat anti-rat antibody IgGs (1:500, $30 \mathrm{~min}$, Abcam, Cambridge, UK), followed by an intensification of the signal with an avidin-biotin-horseradish peroxidase solution ( 2 h, Vectastain Elite ABC, Vector Laboratories, Burlingame, CA).

For the three antibodies immunostaining was done using the glucose oxidase-diaminobenzidine-nickel method which results in a black staining pattern $[55,59,60]$. Vibratome sections were mounted on gelatin-coated glass slides. Finally, vibratome and cryostat sections were dehydrated, cleared, cover-slipped and series of sections from each tissue were analyzed with a light microscope (Imager Z1, Zeiss) and photographs were made with an Axiocam MRc5 camera and Axiovision software.

Omission of the primary antibodies abolished the immunocytochemical staining completely, indicating method specificity.

\subsection{Histology}

Histology was performed to aid interpretation of the distribution patterns obtained by in situ hybridization and immunocytochemistry. For brain, adjacent sections were Nissl stained (Cresyl 
A

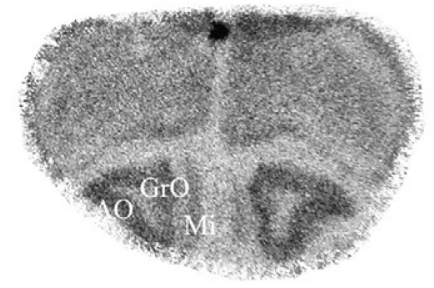

$\mathrm{C}$

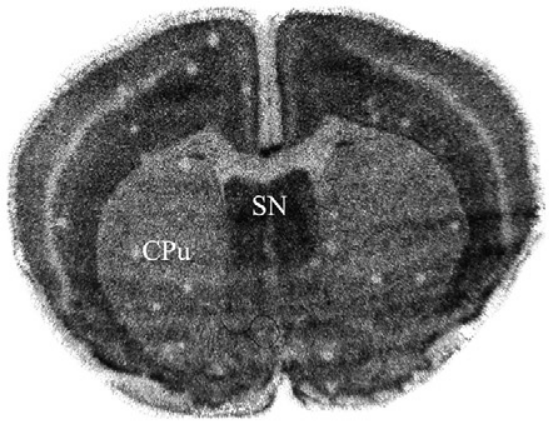

$\mathrm{F}$

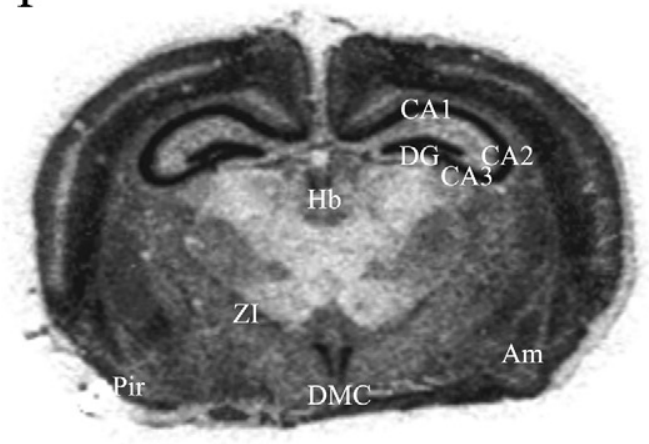

K

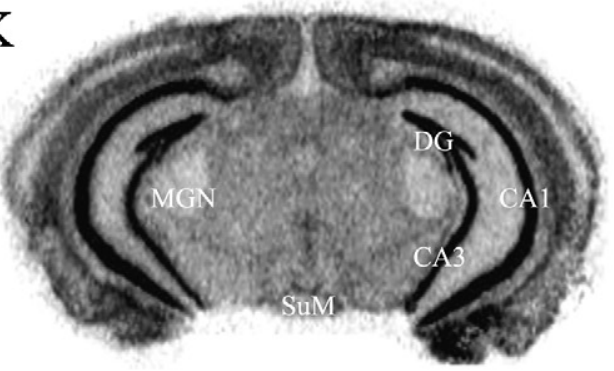

M

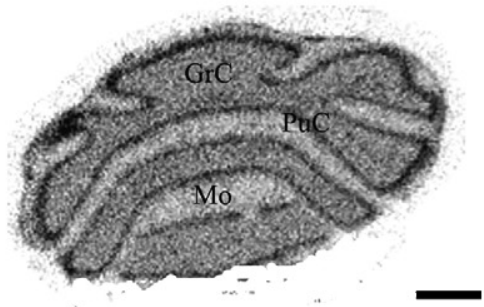

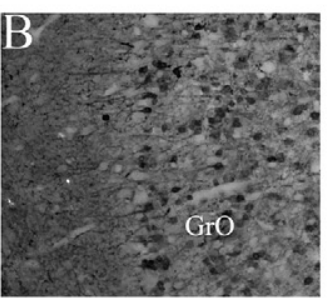
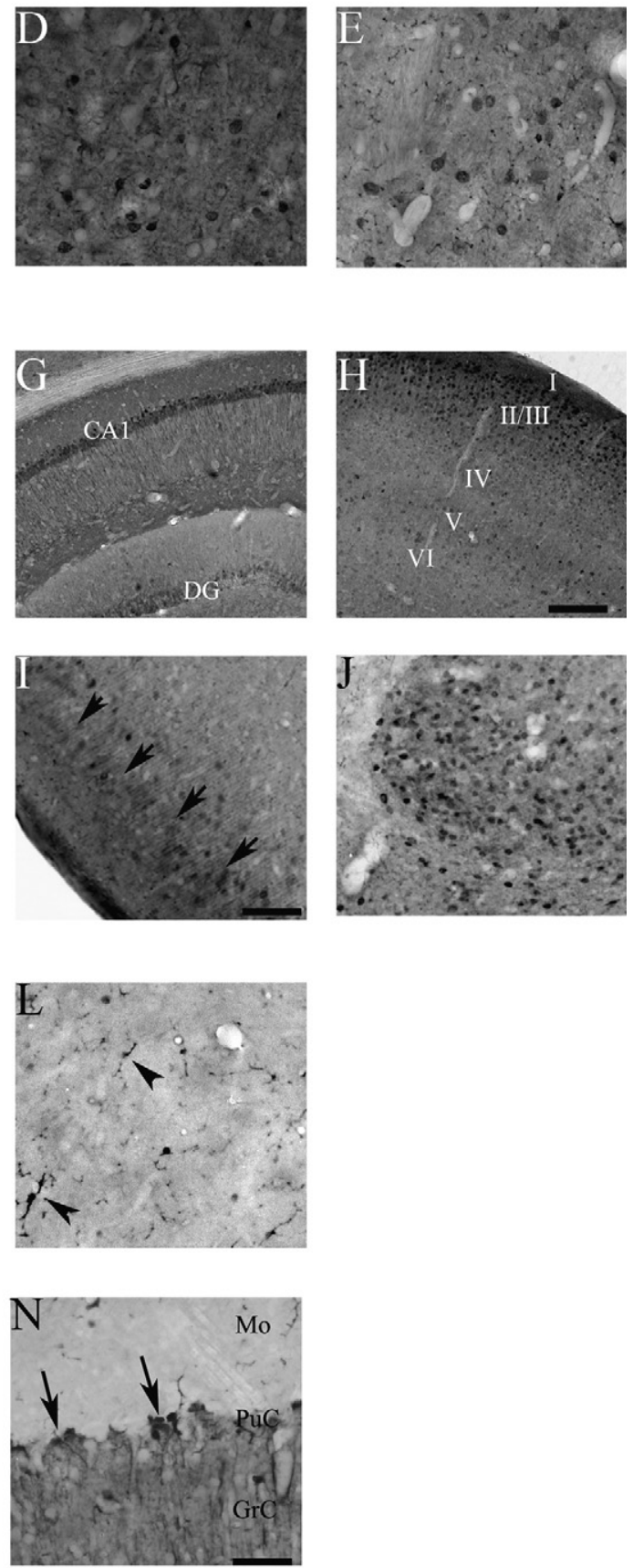

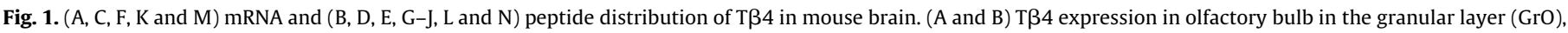

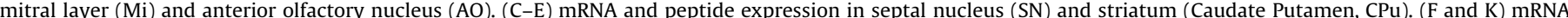

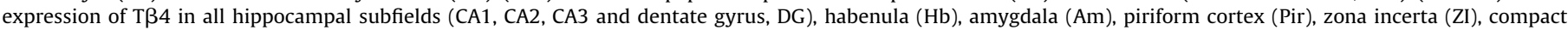

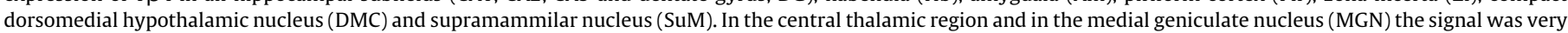

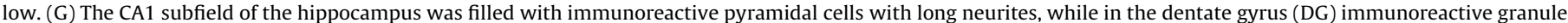

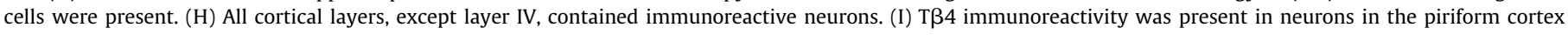

Please cite this article in press as: Paulussen M, et al. Thymosin beta 4 mRNA and peptide expression in phagocytic cells of different mouse tissues. Peptides (2009), doi:10.1016/j.peptides.2009.07.010 
violet $1 \%$, Fluka Chemika, Sigma-Aldrich) according to standard procedures. For the peripheral organs adjacent sections were stained with a standard Mayer's Haematoxilin protocol.

\section{Results}

\section{1. $T \beta 4$ in mouse brain}

\subsubsection{Precursor $m R N A$}

In the olfactory bulb, the T $\beta 4$ mRNA was predominantly situated in the granular layer and the anterior olfactory nucleus; a much less intense signal was visible in the mitral cell layer (Fig. 1A). More posterior from the olfactory bulb the septal nucleus was clearly T $\beta 4$-positive, while a less dark signal was found in the striatum (Fig. 1C). At more posterior levels T $\beta 4$ mRNA was located in the hippocampus, habenula, zona incerta, compact dorsomedial hypothalamic nucleus, piriform cortex, amygdala and supramammilary nucleus. Centrally in the thalamic region and in the medial geniculate nucleus no signal above background was detected (Fig. 1F and $\mathrm{K}$ ). With the dentate gyrus, CA1, CA2 and CA3 subfield, all hippocampal subfields expressed T $\beta 4$ mRNA in equal amounts (Fig. $1 \mathrm{~F}$ and $\mathrm{K}$ ). The neocortex was $\mathrm{T} \beta 4$-positive throughout the entire brain. All cortical layers, except layer IV, expressed a dark mRNA signal (Fig. 1C, F and $\mathrm{K}$ ). Also, the white matter was positive for T $\beta 4$ mRNA. Finally, in the cerebellum T $\beta 4$ mRNA was most prominent in the granular layer and the Purkinje cell layer (Fig. 1M).

\subsubsection{Cellular localization by immunocytochemistry}

Far anterior in the brain intensely stained T $\beta 4$-immunoreactive neurons were found in the granular layer of the olfactory bulb (Fig. 1B). In the septal nucleus, the dark mRNA signal corresponded well with the large number of dark $\mathrm{T} \beta 4$-immunoreactive neurons (Fig. 1D). The amount of T $\beta 4$ mRNA was lower in the striatum, which is reflected by fewer and more lightly stained neurons (Fig. 1E). T $\beta 4$-immunoreactive pyramidal cells with long neurites were clearly visible in the CA-subfields; in the dentate gyrus, granular cells are T $\beta 4$-positive (Fig. 1G). Layer IV of the neocortex was devoid of T $\beta 4$ immunoreactivity, while in layers II/III, V and VI T $\beta 4$-immunoreactive neurons appeared widespread (Fig. $1 \mathrm{H}$ ). In general, mRNA and peptide expression level and distribution seemed to fit well, as further illustrated for the piriform cortex (Fig. 1I) and the amygdala (Fig. 1J). In the cerebellum, at the border between the granular and the molecular layer, an intensely stained layer was visible, consisting of T $\beta 4$-immunoreactive basket cell axons surrounding the unstained cell bodies of the Purkinje cells (Fig. $1 \mathrm{~N}$ ).

Besides neurons, $\mathrm{T} \beta 4$-immunoreactive microglia were detected throughout the entire brain. Microglia, the macrophages of the brain, were recognizable through their small cell bodies with long ramified processes. The $\mathrm{T} \beta 4$-immunoreactive microglia were not restricted to specific areas like the neurons, but appeared scattered throughout the entire brain. Brain areas with low mRNA signal intensity, like the thalamic region, the white matter, the medial geniculate nucleus or the molecular layer of the cerebellum typically showed only T $\beta 4$-immunoreactive microglia, but no immunopositive neurons (Fig. $1 \mathrm{~L}$ ).

When comparing $\mathrm{T} \beta 4$ with CD11b immunocytochemistry patterns, we observed that the $\mathrm{CD} 11 \mathrm{~b}$ antiserum stained many more microglia than T 34 in the neocortex. Yet with the CD11b antibody only microglia were stained, whereas with the T $\beta 4$ antiserum both microglia as well as neurons stained positive
$\mathrm{T} \beta 4$
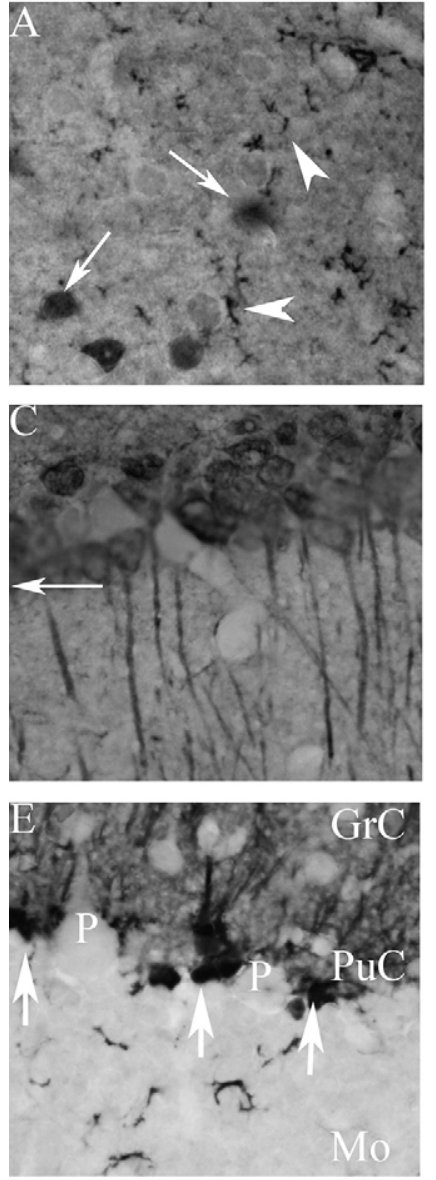

$\mathrm{CD} 11 \mathrm{~b}$
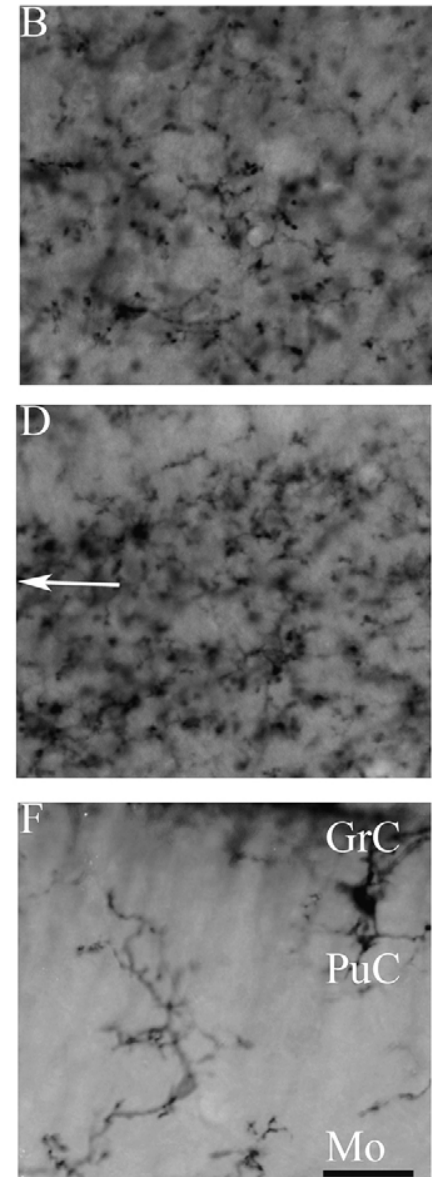

Fig. 2. Comparison of the cellular localization of (A, C and E) T 34 and (B, D and F) CD11b immunoreactivity in mouse brain. (A) In neocortex T 34 immunoreactivity was found in neurons (arrows) and microglia (arrowheads) (B) CD11b in neocortex only stained microglia. (C) In the hippocampal CA1 subfield pyramidal neurons with long processes stained with the $\mathrm{T} \beta 4$ antibody: stained microglia are sporadically present. (D) On the same level in the hippocampus (arrow) CD11b stained only microglia, but no neurons. (E) In the cerebellum, the most intensely stained cells were the basket cells (arrows) that surround the Purkinje cells (P) in the Purkinje cell layer (PuC). (F) $\mathrm{CD} 11 \mathrm{~b}$ on the same level in the cerebellum stained only microglia. Bar $50 \mu \mathrm{m}$.

(Fig. 2A and B). In the CA1 subfield of the hippocampus pyramidal neurons with long processes were seen with the T $\beta 4$ antibody, whereas microglia were difficult to distinguish (Fig. 2C). Looking in the same subfield with the CD11b antibody, only microglia were detected (Fig. 2D). In the cerebellum, the basket cell axon terminals surrounding the Purkinje cells were most intensely stained. Fig. 2E illustrates immunopositive basket cell axons surrounding immunonegative Purkinje cells. T $\beta 4$-positive microglial fibers were abundant in the granular as well as in the molecular layer (Fig. 2E). Again with the CD11b antibody immunoreactive microglia were present throughout all cerebellar layers (Fig. 2F).

\section{2. $T \beta 4$ in peripheral mouse organs}

\subsubsection{Precursor $m R N A$}

T $\beta 4$ mRNA was expressed in the kidney, liver, spleen, thymus, stomach, intestine, lung and adrenal gland (Fig. 3). In contrast, no

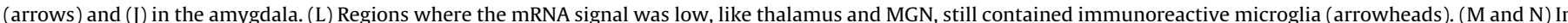

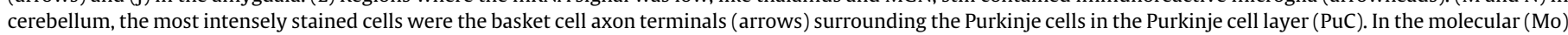

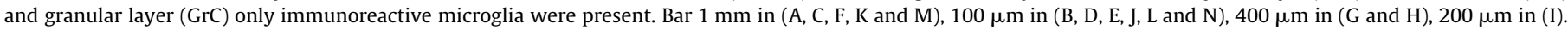



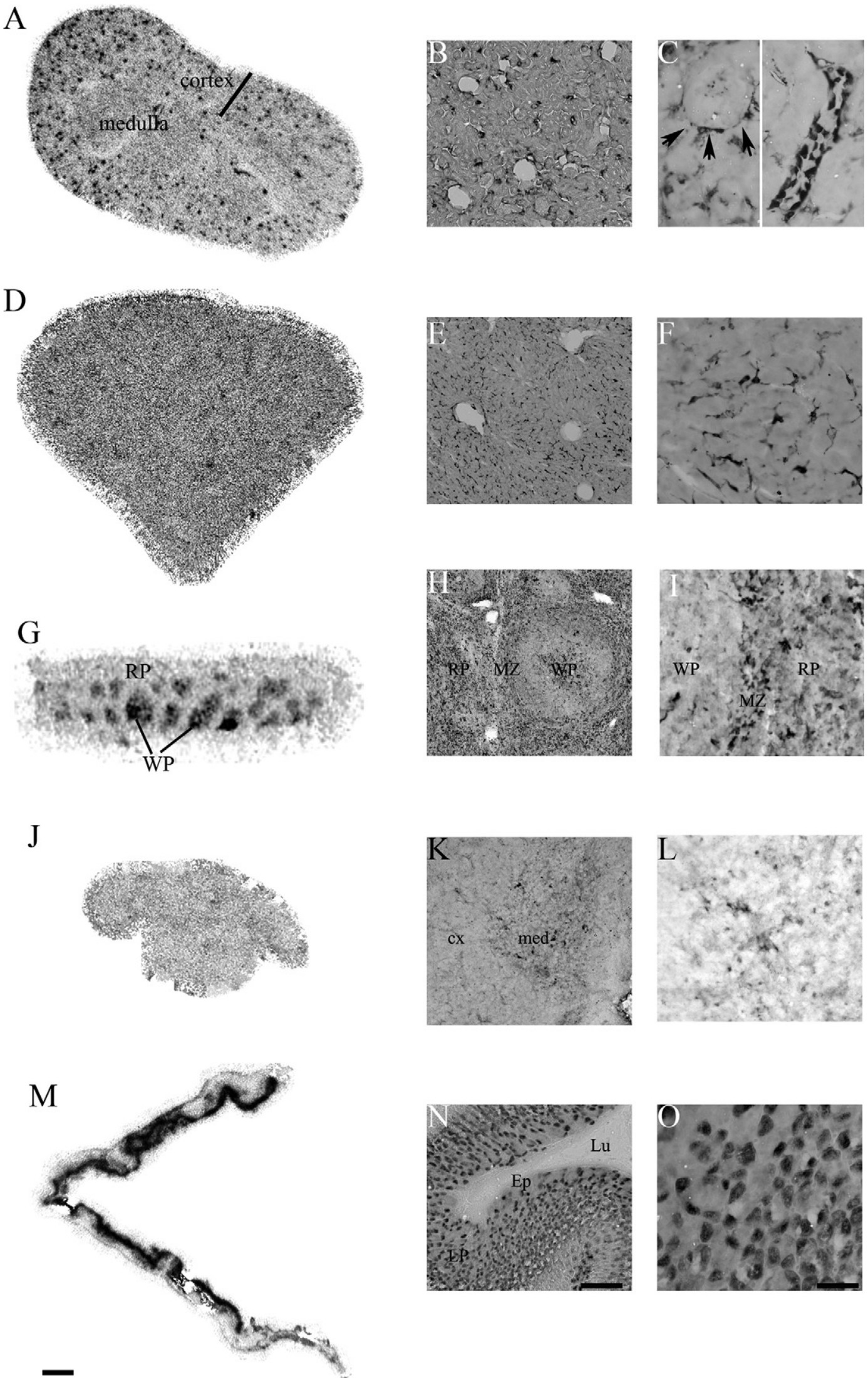

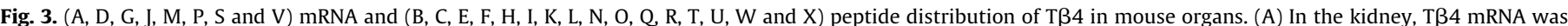

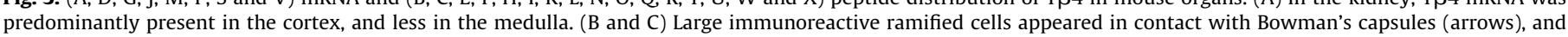

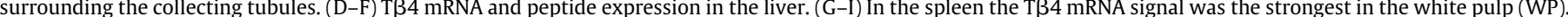

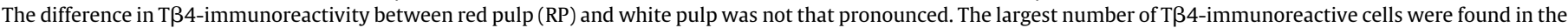

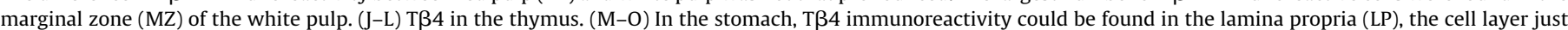

Please cite this article in press as: Paulussen M, et al. Thymosin beta 4 mRNA and peptide expression in phagocytic cells of different mouse tissues. Peptides (2009), doi:10.1016/j.peptides.2009.07.010 
$\mathrm{P}$

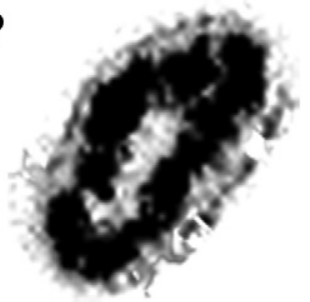

Q

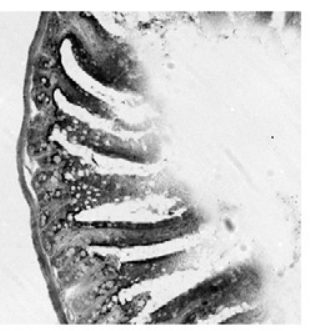

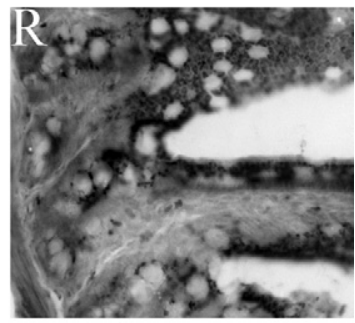
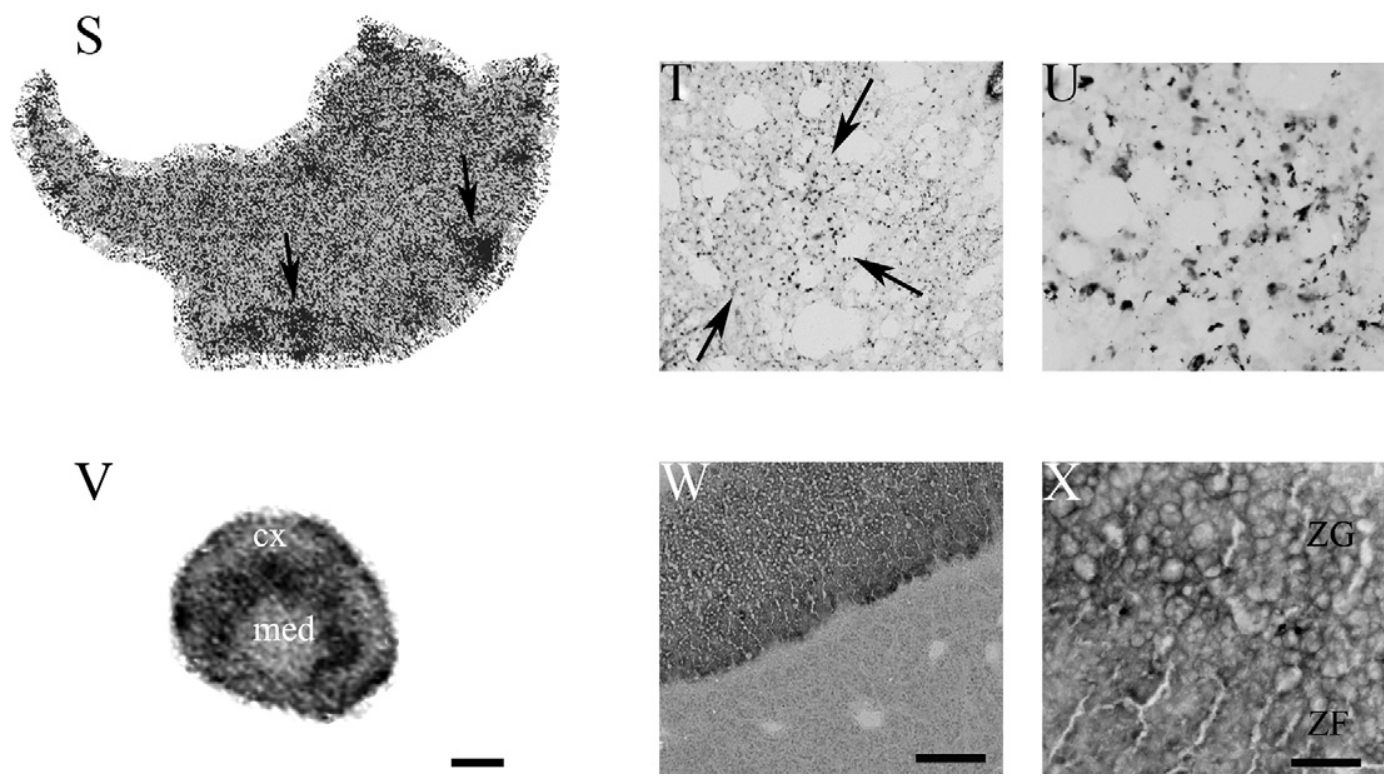

Fig. 3. (Continued).

specific signal was detected in the pancreas or the pituitary. Heart, ovary and testis were not included in this study.

In the kidney, T $\beta 4$ mRNA was present in discrete, punctate structures both in the cortex and the medulla, but more extensively in the cortex (Fig. 3A). In the liver, spots of high intensity were spread along the entire organ (Fig. 3D). T $\beta 4$ mRNA in spleen was most prominent in the white pulp region, with moderate expression in red pulp regions (Fig. 3G). The mRNA signal in the thymus was difficult to distinguish from background (Fig. 3J), while in the stomach and intestine, mRNA expression was very intense (Fig. $3 \mathrm{M}$ and $\mathrm{P}$ ). The $\mathrm{T} \beta 4$-positive signal in the stomach was situated in the lamina propria, the cell layer just beneath the epithelial layer. In lung tissue, a punctate signal grouped in patches was distributed across the organ (Fig. 3S). Finally, in the adrenal gland, T $\beta 4$ mRNA was very extensively expressed in the cortex, but much less in the medulla (Fig. $3 \mathrm{~V}$ ).

\subsubsection{Cellular localization by immunocytochemistry}

The morphology of the immunoreactive cells was similar in kidney and liver: characteristic for the T $\beta 4$-immunoreactive cells are the small cell bodies with long branched processes (Fig. 3B, C, E and $F$ ). In the kidney, these cells were clearly in direct contact with Bowman's capsule and lining the collecting tubules (Fig. 3C). In the liver, $\mathrm{T} \beta 4$-immunoreactive cells were distributed across the entire organ, although more concentrated towards the portal veins (Fig. 3E). T $\beta 4$-immunoreactive cells were present throughout the entire spleen, although the marginal zone of the white pulp was stained more intensely. In red as in white pulp, all cells again had ramified processes, but these are typically smaller than in kidney and liver (Fig. $3 \mathrm{H}$ and I). No clear T $\beta 4$ mRNA signal was detected in the thymus, but with immunocytochemistry, a few T $\beta 4$-positive cells could be seen (Fig. $3 \mathrm{~K}$ and $\mathrm{L}$ ). These cells were present in the cortex and medulla, but more abundantly in the medulla. In the thymus, no large cells with ramifications were found. The immunoreactive elements here were relatively small and round or had a fiber-like structure. Also in the stomach, the T $\beta 4$ immunoreactive cells did not have large processes, but were large and round (Fig. 30). These cells were all located in the lamina propria (Fig. $3 \mathrm{~N}$ ). In contrast, in the intestine the immunopositive signal mainly lined the intestinal villi, although also some immunoreactive cells were found in the lamina propria (Fig. $3 \mathrm{Q}$ and $\mathrm{R}$ ). In the lung, intensely immunostained cells were visible (Fig. 3U). These round cells were present throughout the entire lung, although areas of higher abundance were visible (Fig. 3T), comparable with detection at the mRNA level (Fig. 3S). In the adrenal medulla, a very small number of T $\beta 4$-immunoreactive cells were present, while the adrenal cortex was intensely stained (Fig. 3W). The outer zona glomerulosa contained the most positive cells, followed by the zona fasciculata below it. These cells again had large ramified branches (Fig. 3X).

To reveal whether the $\mathrm{T} \beta 4$ immunoreactivity was located in macrophages, a comparison was made with an antibody to CD11b, a conventional macrophage marker. Since a few tissues did not show the same immunoreactivity patterns, an additional, more classical, macrophage marker was used, allowing comparison with the two markers. In the kidney (Fig. 4A-C) and the liver (Fig. 4D-F),

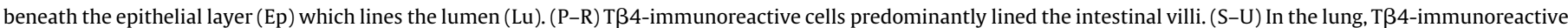

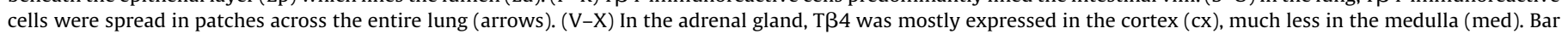
$1 \mathrm{~mm}$ in (A, D, G, J, M, P, S an dV), $400 \mu \mathrm{m}$ in (B, E, H, K, N Q T and W), $100 \mu \mathrm{m}$ in (C, F, I, L, O, R, U and X). 
$\mathrm{T} \beta 4$

(A)

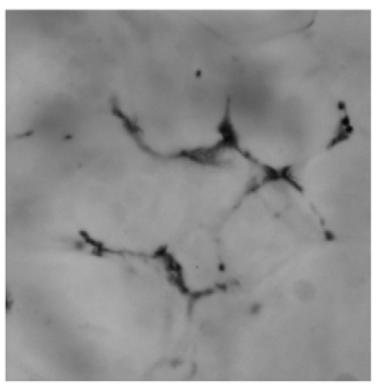

(D)

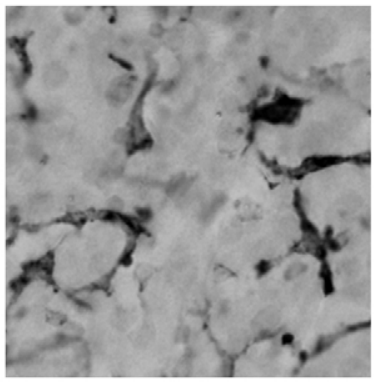

(G)

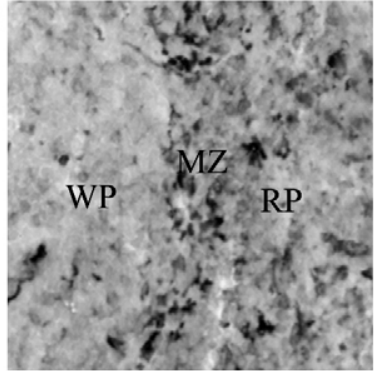

(J)

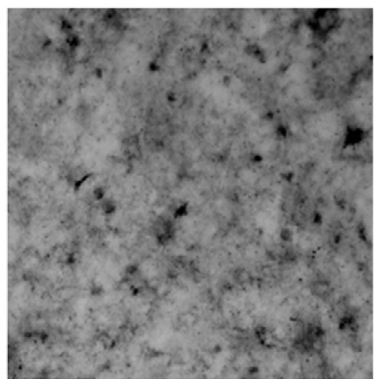

(M)

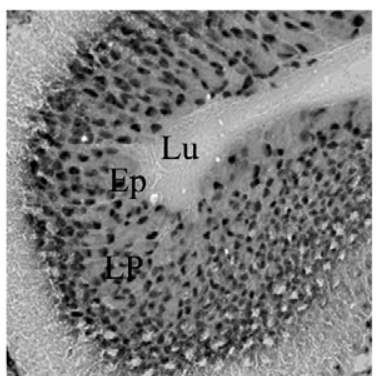

(B)

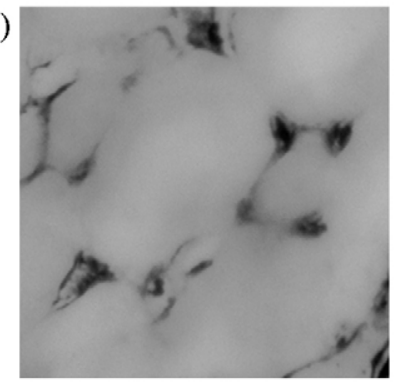

(E)

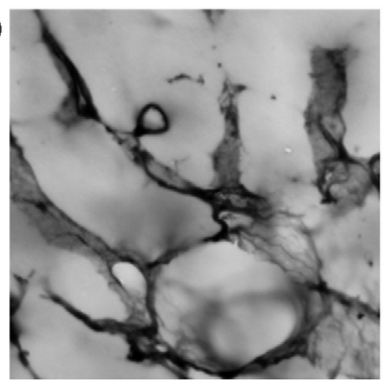

(H)

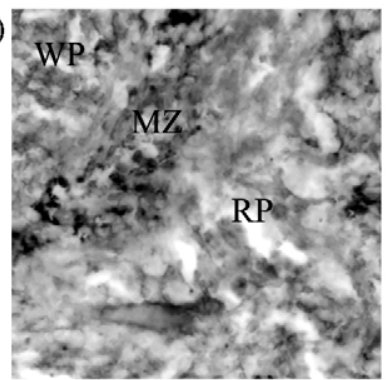

(K)

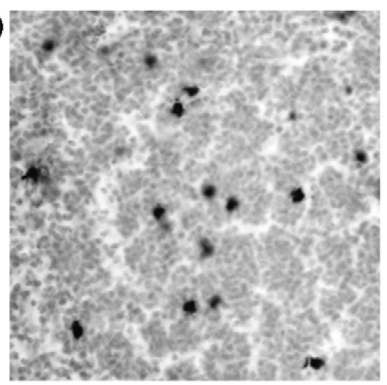

(N)

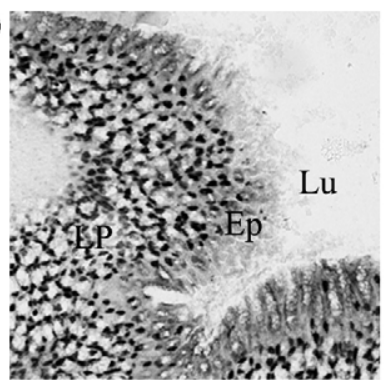

CD68

(C)

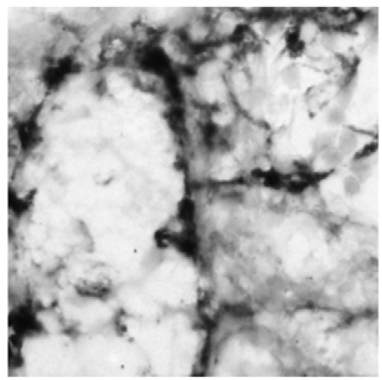

(F)

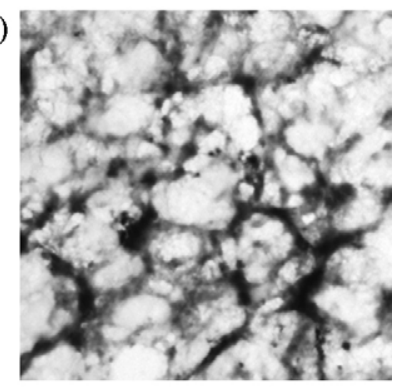

(I)

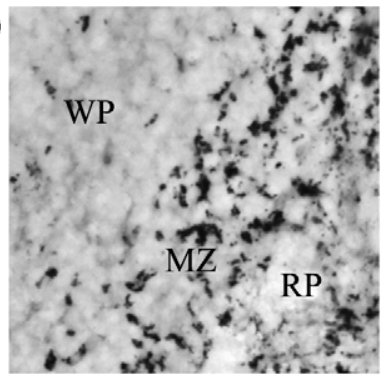

(L)

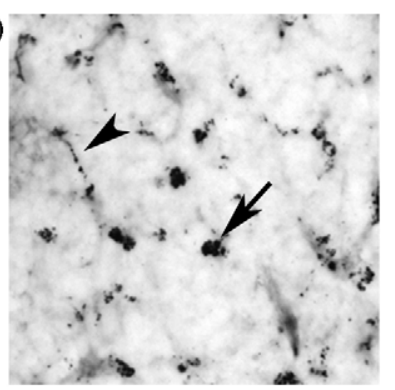

(O)

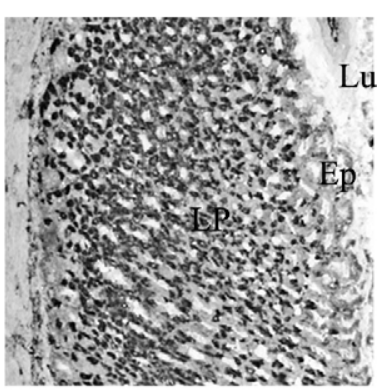

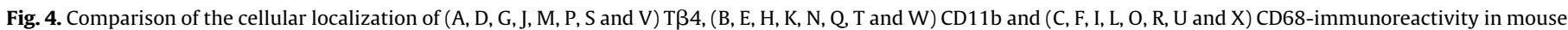

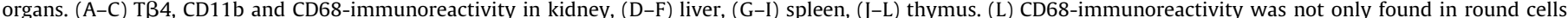

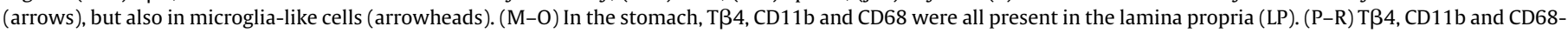

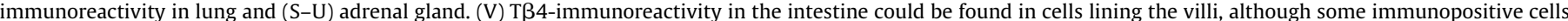

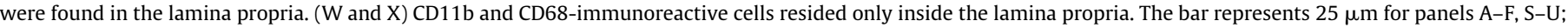
$50 \mu \mathrm{m}$ for panels $\mathrm{G}-\mathrm{L}, \mathrm{V}-\mathrm{X}$, and $200 \mu \mathrm{m}$ for panels M-R.

Please cite this article in press as: Paulussen M, et al. Thymosin beta 4 mRNA and peptide expression in phagocytic cells of different mouse tissues. Peptides (2009), doi:10.1016/j.peptides.2009.07.010 
(P)

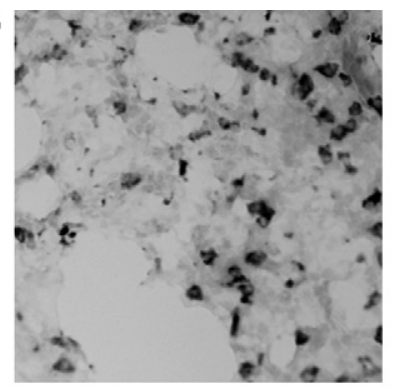

(S)

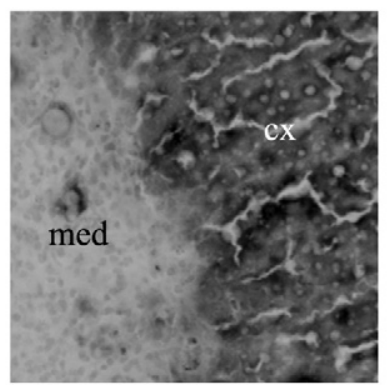

(V)

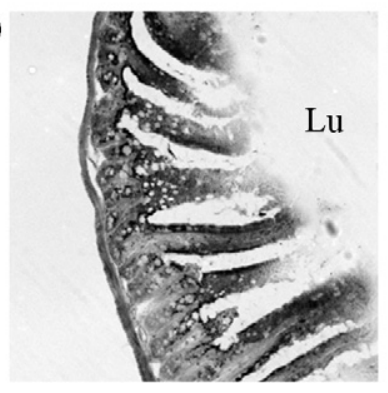

(Q)

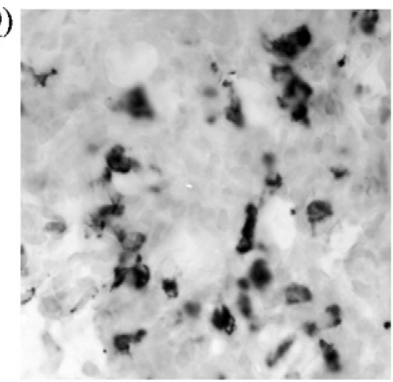

(T)

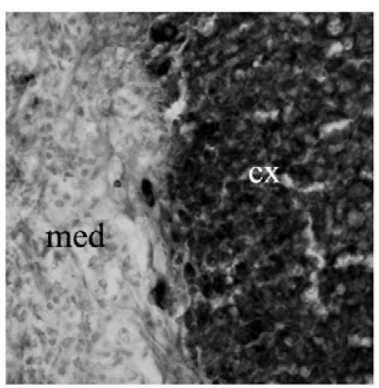

(W)

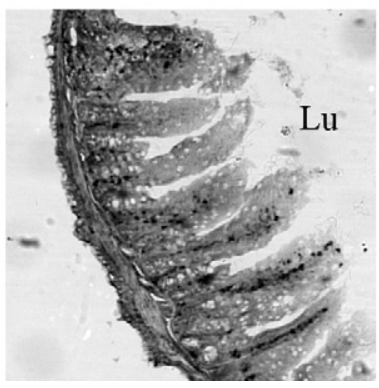

(R)

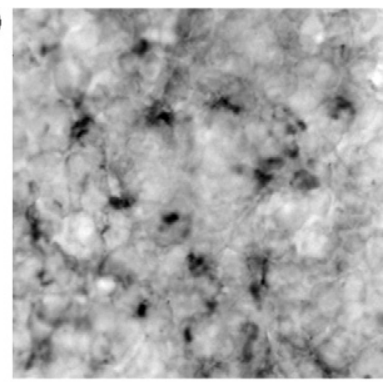

(U)

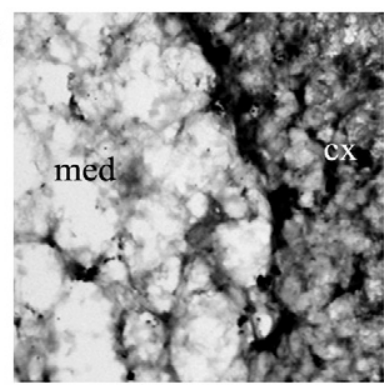

(X)

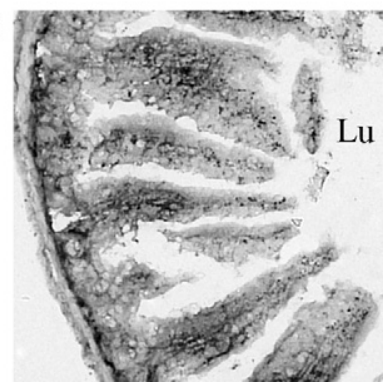

Fig. 4. (Continued)

the T $\beta 4, C D 11 \mathrm{~b}$ and CD68-immunoreactive cells displayed the same morphology. Although in the liver many more macrophages were stained with the CD11b and the CD68 antibodies than with the $\mathrm{T} \beta 4$ antibody, all these cells had the typical macrophage-like small cell bodies with ramified processes (Fig. 4D-F). In the kidney, CD68-immunoreactivity was more intense than T $\beta 4$ and CD11bimmunoreactivity (Fig. $4 \mathrm{~A}-\mathrm{C}$ ). Like for $\mathrm{T} \beta 4$, a lot more cells were stained in the cortex than in the medulla (not shown). In the spleen (Fig. 4G-I), the most intense staining was seen in the marginal zone for T $\beta 4$, as well as for CD11b and CD68. Furthermore, there were immunoreactive cells seen in the center of the white pulp and in the red pulp with the three antibodies. As shown in Fig. 4K, with the $\mathrm{CD} 11 \mathrm{~b}$ antibody, small round cells stained in the thymus, predominantly in the medulla. With the T $\beta 4$ and the CD68 antibodies, the same round cells were present, but additional microglia-like cells were found immunopositive (Fig. 4J and L). With the CD68 antibody, staining was more spread across the entire thymus, while the T $\beta 4$-immunopositive cells were predominantly located in the medulla. In the stomach (Fig. 4M-O), the same pattern could be seen with the T $\beta 4$ as with the CD11b and CD68 antibodies: large round cells located in the lamina propria. In the lung (Fig. 4P-R), the same round cells and some fiber-like structures were intensely stained with the three antibodies. Also in the adrenal gland (Fig. 4S-U), the immunostaining for T $\beta 4, C D 11 \mathrm{~b}$ and CD68 matched, with a very prominent signal of large, dark, ramified cells in the cortex, while only a few cells were stained in the medulla. Although in adrenal medulla CD68-immunopositive cells were more abundant than T $\beta 4$ and CD11b-immunopositive cells.

While in all the aforementioned organs the immunostaining pattern for T $\beta 4$ corresponded well with that for CD11b and CD68, remarkably, in the intestine this pattern was definitely different (Fig. 4V-X). While many $\mathrm{T} \beta 4$-immunoreactive cells lined the intestinal villi, the CD11b and CD68-immunoreactive cells were only located in the lamina propria.

\section{Discussion}

In this study, $\mathrm{T} \beta 4$ was semi-quantitatively located in a subpopulation of resting macrophages in the brain, kidney, liver, spleen, thymus, stomach, intestine, lung and adrenal gland with in situ hybridization and immunocytochemistry.

Macrophages exhibit very different phenotypes in different tissues, and sometimes even within the same tissue [40,45,64]. They can be recognized by their typical amoeboid morphology with a large nucleus, and they are filled with many lyso- and phagosomes. Macrophages are very motile cells with secretory activity. They act as first defense against foreign particles and phagocytose cellular debris, viruses and bacteria [15,40,61].

The CD11b antibody is directed against an epitope on CR3. This receptor is not only situated on macrophages, but also on blood monocytes, granulocytes and natural killer cells [3,6,52]. Monocytes and granulocytes circulate in the blood and leave the blood stream only at inflammation sites. Besides in the blood circulation, natural killer cells are also present in normal tissue. Therefore these cells cannot be excluded in this study, but the typical macrophage-like morphology of the T $\beta 4$-positive cells does suggest that these cells in fact are macrophages and not natural killer cells. Also in literature no relation between T $\beta 4$ and natural killer cells has been suggested, while the peptide is correlated frequently with macrophages [24,28,65]. 
In the intestine the $\mathrm{CD} 11 \mathrm{~b}$ antibody revealed a different cellular distribution compared to the $\mathrm{T} \beta 4$ antibody. We therefore introduced CD68 as an additional macrophage marker to better understand the T $\beta 4$ expression patterns within the different tissues. CD68 was chosen as a second marker because of its wide distribution in macrophages of different tissues at various differentiation stages and activation states [32]. Macrosialin, the murine homolog of the human macrophage glycoprotein CD68, is a heavily glycosylated transmembrane protein sharing homology with the lysosomal-associated membrane protein (LAMP-1) family, specifically expressed by most tissue macrophages, blood monocytes and myeloid dendritic cells [25,32,50].

Since cell migration and phagocytosis, two important characteristics of macrophages/microglia, are both actin-mediated activities, T $\beta 4$ may indirectly control these processes [4,14,53]. Indeed, T $\beta 4$ 's main function is that of a G-actin sequestering peptide [53]. T $\beta 4$ sequesters monomeric $G$-actin in such a way that it is unable to polymerize into F-actin. In this way T $\beta 4$ constantly regulates actin function.

\section{1. $T \beta 4$ in mouse brain}

$\mathrm{T} \beta 4$ is widespread in the brain, in neurons as in microglia. The immunoreactive neurons were restricted to specific locations, while the immunoreactive microglia were spread throughout the entire brain. Areas where no T $\beta 4$-immunoreactive neurons were detected, like the thalamic region, the molecular layer of the cerebellum or the white matter, did contain T $\beta 4$-immunoreactive microglia. The CD11b-immunoreactive microglial population was much larger than the T $\beta 4$-immunoreactive microglial population. This could indicate that T $\beta 4$ is only expressed by a microglial subgroup.

$\mathrm{T} \beta 4$ has a double function in the brain. Via its association with microglia and its actin sequestering activity, T $\beta 4$ plays an indirect role after brain lesions; e.g. hippocampal deafferentiation [17], brain ischemia [62], kainate neurotoxicity [7,48]. In all these cases a substantial upregulation of $\mathrm{T} \beta 4$ is observed. After a lesion, microglia are activated and start clearing debris of degenerating axons and myelin to make room for axonal sprouting. Furthermore microglia activate astrocytes, which can give axonal guidance cues $[5,17]$. Yoshida et al. found an upregulation of $\mathrm{T} \beta 4$ after ischemia in kidney comparable to that in the brain [67], so a general role for $\mathrm{T} \beta 4$ after tissue damage can be expected.

Apart from microglial activation, T 34 participates in growth and remodeling of neuronal processes $[1,7,21,48,62]$. Moreover, it is implicated in synaptic plasticity and neurite outgrowth. T $\beta 4$ immunoreactive neurons have longer processes and a more extensive arborization and T $\beta 4$ enhances neuronal survival [66]. Actin polymerization is a crucial event for cellular motility and thus for axonal pathfinding and synaptogenesis, explaining T $\beta 4$ 's role in lesion-induced plasticity $[7,17,21,48,66]$.

\section{2. $T \beta 4$ in mouse organs}

\subsubsection{Kidney}

Literature is scarce on distribution, function and regulation of macrophages in the kidney. With the F4/80 macrophage antibody it was shown that macrophages in the kidney are predominantly present throughout the medulla. They were recognizable by their typical macrophage morphology. They covered the outer surface of the collecting tubes, proximal and distal tubules and they were located around Bowman's capsules [34]. Also with the CD68, $\mathrm{CD} 11 \mathrm{~b}$ and $\mathrm{T} \beta 4$ antibodies, the typical amoeboid morphology with long processes was observed and the stained cells were also found lining up collecting tubules and around Bowman's capsule. Macrophages in the kidney are a source of prostaglandin E; they could play a central role in the regulation of renal physiology, and a role in erythropoiesis is suggested in the literature [34]. T及4 function in renal macrophages is probably related to its G-actin sequestering activity. In case of an inflammation, macrophages migrate towards the site of inflammation. This motility is dependent on actin polymerization, a function ascribed to T $\beta 4$. Besides this, phagocytic macrophages need actin for invaginations of the cell membrane. Phagocytosis is only possible through a reorganization of the actin cytoskeleton $[4,14,17,53]$.

\subsubsection{Liver}

Kupffer cells are the most abundant macrophages in the body: they are located in the lumen of hepatic sinusoids and are attached to the outer surface of endothelial cells [40]. Apart from clearing debris, secreting cytokines and other typical macrophage functions, Kupffer cells also serve as modulators of hepatocyte proliferation [58]. With both the T $\beta 4$ antibody and the two macrophage markers, the immunoreactive cells had a similar morphology as in the kidney and could be regarded as macrophages/Kupffer cells. These cells were found throughout the entire liver; but their number increased towards the portal veins, confirming their close association with the vasculature. The CD11b and the CD68 antibodies stained many more Kupffer cells than the T $\beta 4$ antibody. Hence, here again T $\beta 4$ was only expressed in a Kupffer cell subgroup. So far, no specific function has been attributed to $\mathrm{T} \beta 4$ in the liver; like in kidney, it can play a role in actin polymerization and thus regulate migration and phagocytosis of the Kupffer cells.

\subsubsection{Spleen}

Using the F4/80 antibody Hume et al. showed that the white pulp of the spleen is practically devoid of macrophages, while the red pulp is loaded with them [37]. Logically, macrophages are abundant in the red pulp, because of their function as a blood filter [9]. The macrophages in the marginal zone and in the white pulp clear the spleen from micro-organisms [9]. In this study, macrophages were found in both red and white pulp; the most prominent expression pattern with $\mathrm{CD} 11 \mathrm{~b}, \mathrm{CD} 68$ and $\mathrm{T} \beta 4$ antibodies was located in the marginal zone. Besides the regulation of actin metabolism for migration and phagocytosis by macrophages, Gondo et al. described another function, namely that T $\beta 4$ controls phenotypical changes in T-cell lines [24].

\subsubsection{Thymus}

$\mathrm{T} \beta 4$ was originally isolated from calf thymus, as part of thymosin fraction 5 [42,43], although the amount of $\mathrm{T} \beta 4$ in thymus is low in comparison with other organs, which was also confirmed in a quantitative study by Lee et al. [41]. With the F4/80 antibody, Hume et al. detected the presence of different types of macrophages in the thymus. In the thymic cortex, macrophages had a microglial-like morphology, while in the medulla, macrophages could be subdivided in a microglia-like group and a group of cells with a round appearance [37]. In the cortex, a lot more macrophages are needed than in the medulla, because positive and negative selection predominantly takes place in the cortex, where many lymphocytes undergo apoptosis and have to be phagocytized [47]. The epithelial cells, that produce a number of thymic hormones, including $\mathrm{T} \beta 4$, are situated predominantly in the medulla [47]. Interestingly, CD11b and T $\beta 4$ immunoreactivity was found especially in the medulla. On the other hand, CD68 was expressed across the entire thymus, suggesting that the T $\beta 4$ antibody does recognize only a subset of macrophages. Yet the T $\beta 4$ and the CD68 antibodies recognized cells of similar morphology including microglia-like and round cells, while the CD11b only stained round cells. Besides the normal G-actin sequestering function, $\mathrm{T} \beta 4$ is also implicated in T-cell maturation and differentiation in the thymus $[43,47]$. 


\subsubsection{Stomach and intestine}

In the stomach and intestine, the lamina propria is densely filled with macrophages $[15,33,36,37,41]$. Denning et al. showed CD11bimmunoreactive macrophages scattered throughout the lamina propria of the intestinal villi along the entire intestine. Phenotyping revealed that the $\mathrm{CD} 11 \mathrm{~b}$-immunoreactive cells were indeed macrophages and not natural killer cells [15]. Macrophages stained with the CD11b and the CD68 antibodies were indeed typically seen in the lamina propria of the stomach and intestine. In the stomach the same pattern was seen with $T \beta 4$. In the intestine however the T $\beta 4$-immunoreactive cells clearly also lined the villi. These T $\beta 4$-immunopositive cells were located in the epithelium of the intestines. Because of their close lining of the villi and their high cylindrical shape, these $\mathrm{T} \beta 4$-positive cells could be identified as enterocytes [57]. Intestinal macrophages clear debris, respond to luminal contents by transporting intestinal particles, like bacteria, into extraintestinal sites, and they produce a range of cytokines. In the stomach, macrophages are a source of prostaglandin E, which controls acid secretion $[15,33,63]$. Here, T $\beta 4$ most likely functions as a G-actin sequestering peptide to arrange changes in macrophage morphology and migration. No other functions in the gastrointestinal tract are known.

\subsubsection{Lung}

There are two types of macrophages in the lung, which morphologically are not easy to distinguish: the alveolar macrophages in the alveolus and the interstitial macrophages in the lung parenchyma. The alveolar macrophages are involved in the primary defense against inhaled particles [40]. Lung macrophages are round cells present throughout the entire lung [16,19], a pattern observed with $\mathrm{CD} 68, \mathrm{CD} 11 \mathrm{~b}$ and $\mathrm{T} \beta 4$ antibodies. No specific lung functions have yet been attributed to $\mathrm{T} \beta 4$.

\subsubsection{Adrenal gland}

In the adrenal gland F4/80-immunoreactive macrophages were predominantly present in the cortex, with the highest density in the outer zona glomerulosa, and lower density in the layer below, the zona fasciculata. In the adrenal medulla, macrophages were sparse [35]. CD11b, CD68 and T $\beta 4$-immunoreactive cells had the same distribution pattern, they were mainly found in the zona glomerulosa of the adrenal cortex; while in the adrenal medulla only a few immunoreactive cells were found. With the CD68 antibody more immunoreactive cells were observed in the medulla than with the T $\beta 4$ and $C D 11 \mathrm{~b}$ antibodies, which again indicates that the latter were only expressed by a macrophage subgroup in adrenal medulla. Next to their phagocytotic activity, macrophages in the adrenal gland control extracellular processing of peptide hormones, secrete prostaglandins $\mathrm{E}$ and produce cytokines, which can influence hormone production, the main function of adrenal glands $[35,46]$. These immune-endocrine interactions are important in modulating adrenal responses to inflammatory and immune challenges [46]. T $\beta 4$ probably contributes to this response by controlling actin polymerization to induce cell migration. Although in primates intravenous thymosin fraction 5 (which contains $\mathrm{T} \beta 4$ ), elevates corticotrophin and cortisol concentrations, these glucocorticoids are produced by the zona fasciculata of the adrenal gland cortex [29]. Before ascribing this more specific function to $\mathrm{T} \beta 4$, further research is needed, because fraction 5 contains many peptides that could trigger glucocorticoid secretion.

\section{Conclusion}

Many distinct functions have already been ascribed to T $\beta 4$, though a detailed analysis of its distribution in the whole body of the mouse was lacking, especially at the cellular level. In the present study, we have used two techniques: in situ hybridization to allow an overall screening of the T $\beta 4$ mRNA distribution, and immunocytochemistry for a more precise localization of the peptide at the cellular level. We localized T $\beta 4$ in the brain, thymus, spleen, lung, kidney, liver, adrenal gland, stomach and intestine. Through a comparison with the macrophage differentiation antigen CR3, it was shown that T $\beta 4$ is expressed by almost every type of tissue macrophage, including microglia. In the tissues, a second macrophage marker, CD68, confirmed our findings. Comparison with the two markers made clear that in some tissues $\mathrm{T} \beta 4$ is only expressed by a subgroup of macrophages.

\section{Acknowledgements}

We thank Inge Van der Auwera for her excellent technical assistance. This work was supported by grants from the Institute for the promotion of Innovation by Science and Technology in Flanders (IWT 50164) and by the Fund for Scientific Research, Flanders, Belgium (FWO-Flanders).

\section{References}

[1] Anadon R, Rodriguez MI, Carpintero P, Evangelatos G, Livianou E, Leondiadis L, et al. Differential expression of thymosins beta(4) and beta(10) during rat cerebellum postnatal development. Brain Res 2001;894:255-65.

[2] Arckens L, Zhang F, Vanduffel W, Mailleux P, Vanderhaeghen JJ, Orban GA, et al. Localization of the two protein kinase $C$ beta-mRNA subtypes in cat visual system. J Chem Neuroanat 1995;8:117-24.

[3] Avni O, Pur Z, Yefenof E, Baniyash M. Complement receptor 3 of macrophages is associated with galectin-1-like protein. J Immunol 1998;160:6151-8.

[4] Ballweber E, Hannappel E, Huff T, Stephan H, Haener M, Taschner N, et al. Polymerisation of chemically cross-linked actin:thymosin beta(4) complex to filamentous actin: alteration in helical parameters and visualisation of thymosin beta(4) binding on F-actin. J Mol Biol 2002;315:613-25.

[5] Bechmann I, Nitsch R. Involvement of non-neuronal cells in entorhinal-hippocampal reorganization following lesions. Ann NY Acad Sci 2000;911:192206.

[6] Beller DI, Springer TA, Schreiber RD. Anti-Mac-1 selectively inhibits the mouse and human type three complement receptor. J Exp Med 1982;156:1000-9.

[7] Carpintero P, Anadon R, az-Regueira S, Gomez-Marquez J. Expression of thymosin beta4 messenger RNA in normal and kainate-treated rat forebrain. Neuroscience 1999;90:1433-44.

[8] Carpintero P, Franco del AF, Anadon R, Gomez-Marquez J. Thymosin beta10 mRNA expression during early postimplantation mouse development. FEBS Lett 1996;394:103-6.

[9] Cesta MF. Normal structure, function, and histology of the spleen. Toxicol Pathol 2006;34:455-65.

[10] Cha HJ, Jeong MJ, Kleinman HK. Role of thymosin beta4 in tumor metastasis and angiogenesis. J Natl Cancer Inst 2003;95:1674-80.

[11] Choi SY, Noh MR, Kim DK, Sun W, Kim H. Neuroprotective function of thymosin-beta and its derivative peptides on the programmed cell death of chick and rat neurons. Biochem Biophys Res Commun 2007;362:587-93.

[12] Cnops L, Hu TT, Eysel UT, Arckens L. Effect of binocular retinal lesions on CRMP2 and CRMP4 but not Dyn I and Syt I expression in adult cat area 17. Eur J Neurosci 2007;25:1395-401.

[13] da Silva RP, Gordon S. Phagocytosis stimulates alternative glycosylation of macrosialin (mouse CD68), a macrophage-specific endosomal protein. Biochem J 1999;338(Pt 3):687-94.

[14] Dedova IV, Nikolaeva OP, Safer D, De La Cruz EM, dos Remedios CG. Thymosin beta4 induces a conformational change in actin monomers. Biophys J 2006;90:985-92.

[15] Denning TL, Wang YC, Patel SR, Williams IR, Pulendran B. Lamina propria macrophages and dendritic cells differentially induce regulatory and interleukin 17-producing T cell responses. Nat Immunol 2007;8:1086-94.

[16] Dhami R, He X, Gordon RE, Schuchman EH. Analysis of the lung pathology and alveolar macrophage function in the acid sphingomyelinase-deficient mouse model of Niemann-Pick disease. Lab Invest 2001;81:987-99.

[17] Dong JH, Ying GX, Liu X, Wang WY, Wang Y, Ni ZM, et al. Expression of thymosin beta 4 mRNA by activated microglia in the denervated hippocampus. Neuroreport 2005;16:1629-33.

[18] Erickson-Viitanen S, Ruggieri S, Natalini P, Horecker BL. Distribution of thymosin beta 4 in vertebrate classes. Arch Biochem Biophys 1983;221: 570-6.

[19] Fehrenbach H, Zissel G, Goldmann T, Tschernig T, Vollmer E, Pabst R, et al. Alveolar macrophages are the main source for tumour necrosis factor-alpha in patients with sarcoidosis. Eur Respir J 2003;21:421-8.

[20] Goldstein AL, Low TL, McAdoo M, McClure J, Thurman GB, Rossio J, et al. Thymosin alpha1: isolation and sequence analysis of an immunologically active thymic polypeptide. Proc Natl Acad Sci USA 1977;74:725-9. 
[21] Gomez-Marquez J. Function of prothymosin alpha in chromatin decondensation and expression of thymosin beta-4 linked to angiogenesis and synaptic plasticity. Ann NY Acad Sci 2007;1112:201-9.

[22] Gomez-Marquez J, Anadon R. The beta-thymosins, small actin-binding peptides widely expressed in the developing and adult cerebellum. Cerebellum 2002;1:95-102.

[23] Gomez-Marquez J, Dosil M, Segade F, Bustelo XR, Pichel JG, Dominguez F, et al. Thymosin-beta 4 gene. Preliminary characterization and expression in tissues, thymic cells, and lymphocytes. J Immunol 1989;143:2740-4.

[24] Gondo H, Kudo J, White JW, Barr C, Selvanayagam P, Saunders GF. Differential expression of the human thymosin-beta 4 gene in lymphocytes, macrophages, and granulocytes. J Immunol 1987;139:3840-8.

[25] Gordon S. Macrophage-restricted molecules: role in differentiation and activation. Immunol Lett 1999;65:5-8.

[26] Grant DS, Kinsella JL, Kibbey MC, LaFlamme S, Burbelo PD, Goldstein AL, et al. Matrigel induces thymosin beta 4 gene in differentiating endothelial cells. J Cell Sci 1995;108(Pt 12):3685-94.

[27] Grant DS, Rose W, Yaen C, Goldstein A, Martinez J, Kleinman H. Thymosin beta4 enhances endothelial cell differentiation and angiogenesis. Angiogenesis 1999;3:125-35.

[28] Hannappel E, Xu GJ, Morgan J, Hempstead J, Horecker BL. Thymosin beta 4: a ubiquitous peptide in rat and mouse tissues. Proc Natl Acad Sci USA 1982;79:2172-5.

[29] Healy DL, Hodgen GD, Schulte HM, Chrousos GP, Loriaux DL, Hall NR, et al. The thymus-adrenal connection: thymosin has corticotropin-releasing activity in primates. Science 1983;222:1353-5.

[30] Holness CL, da Silva RP, Fawcett J, Gordon S, Simmons DL. Macrosialin, a mouse macrophage-restricted glycoprotein, is a member of the lamp/lgp family. J Biol Chem 1993;268:9661-6.

[31] Holness CL, Simmons DL. Molecular cloning of CD68, a human macrophage marker related to lysosomal glycoproteins. Blood 1993;81:1607-13.

[32] Horikawa T, Komohara Y, Kiyota E, Terasaki Y, Takagi K, Takeya M. Detection of guinea pig macrophages by a new CD68 monoclonal antibody, PM-1K. J Mol Histol 2006;37:15-25.

[33] Hume DA, Allan W, Hogan PG, Doe WF. Immunohistochemical characterisation of macrophages in human liver and gastrointestinal tract: expression of CD4, HLA-DR, OKM1, and the mature macrophage marker 25F9 in normal and diseased tissue. J Leukoc Biol 1987;42:474-84.

[34] Hume DA, Gordon S. Mononuclear phagocyte system of the mouse defined by immunohistochemical localization of antigen F4/80. Identification of residen macrophages in renal medullary and cortical interstitium and the juxtaglomerular complex. J Exp Med 1983;157:1704-9.

[35] Hume DA, Halpin D, Charlton H, Gordon S. The mononuclear phagocyte system of the mouse defined by immunohistochemical localization of antigen F4/80: macrophages of endocrine organs. Proc Natl Acad Sci USA 1984;81:4174-7.

[36] Hume DA, Perry VH, Gordon S. The mononuclear phagocyte system of the mouse defined by immunohistochemical localisation of antigen F4/80: macrophages associated with epithelia. Anat Rec 1984;210:503-12.

[37] Hume DA, Robinson AP, MacPherson GG, Gordon S. The mononuclear phagocyte system of the mouse defined by immunohistochemical localization of antigen F4/80. Relationship between macrophages, Langerhans cells, reticular cells, and dendritic cells in lymphoid and hematopoietic organs. J Exp Med 1983;158:1522-36

[38] Hutchings P, Rosen H, O’Reilly L, Simpson E, Gordon S, Cooke A. Transfer of diabetes in mice prevented by blockade of adhesion-promoting receptor on macrophages. Nature 1990;348:639-42.

[39] Kim Y, Kim EH, Hong S, Rhyu IJ, Choe J, Sun W, et al. Expression of thymosin beta in the rat brain following transient global ischemia. Brain Res 2006;1085:177-82

[40] Laskin DL, Weinberger B, Laskin JD. Functional heterogeneity in liver and lung macrophages. J Leukoc Biol 2001;70:163-70.

[41] Lee SH, Starkey PM, Gordon S. Quantitative analysis of total macrophage content in adult mouse tissues. Immunochemical studies with monoclonal antibody F4/80. J Exp Med 1985;161:475-89.

[42] Low TL, Goldstein AL. Chemical characterization of thymosin beta 4. J Biol Chem 1982;257:1000-6.
[43] Low TL, Hu SK, Goldstein AL. Complete amino acid sequence of bovine thymosin beta 4 : a thymic hormone that induces terminal deoxynucleotidyl transferase activity in thymocyte populations. Proc Natl Acad Sci USA $1981 ; 78: 1162-6$.

[44] Malinda KM, Sidhu GS, Mani H, Banaudha K, Maheshwari RK, Goldstein AL et al. Thymosin beta4 accelerates wound healing. J Invest Dermatol 1999;113:364-8

[45] Nibbering PH, Leijh PC, van Furth R. Quantitative immunocytochemical characterization of mononuclear phagocytes. II. Monocytes and tissue macrophages. Immunology 1987;62:171-6.

[46] Nussdorfer GG, Mazzocchi G. Immune-endocrine interactions in the mammalian adrenal gland: facts and hypotheses. Int Rev Cytol 1998;183:143-84.

[47] Pearse G. Normal structure, function and histology of the thymus. Toxicol Pathol 2006;34:504-14.

[48] Popoli P, Pepponi R, Martire A, Armida M, Pezzola A, Galluzzo M, et al. Neuroprotective effects of thymosin beta4 in experimental models of excitotoxicity. Ann NY Acad Sci 2007;1112:219-24.

[49] Pulford KA, Sipos A, Cordell JL, Stross WP, Mason DY. Distribution of the CD68 macrophage/myeloid associated antigen. Int Immunol 1990;2:973-80.

[50] Ramprasad MP, Fischer W, Witztum JL, Sambrano GR, Quehenberger O, Steinberg D. The 94- to $97-\mathrm{kDa}$ mouse macrophage membrane protein that recognizes oxidized low density lipoprotein and phosphatidylserine-rich liposomes is identical to macrosialin, the mouse homologue of human CD68. Proc Natl Acad Sci USA 1995;92:9580-4.

[51] Reichert F, Rotshenker S. Complement-receptor-3 and scavenger-receptor-AI/ II mediated myelin phagocytosis in microglia and macrophages. Neurobiol Dis 2003;12:65-72.

[52] Rosen H, Gordon S. Monoclonal antibody to the murine type 3 complement receptor inhibits adhesion of myelomonocytic cells in vitro and inflammatory cell recruitment in vivo. J Exp Med 1987;166:1685-701.

[53] Safer D, Elzinga M, Nachmias VT. Thymosin beta 4 and Fx, an actin-sequestering peptide, are indistinguishable. J Biol Chem 1991;266:4029-32.

[54] Sapp E, Kegel KB, Aronin N, Hashikawa T, Uchiyama Y, Tohyama K, et al. Early and progressive accumulation of reactive microglia in the Huntington disease brain. J Neuropathol Exp Neurol 2001;60:161-72.

[55] Shu SY, Ju G, Fan LZ. The glucose oxidase-DAB-nickel method in peroxidase histochemistry of the nervous system. Neurosci Lett 1988;85:169-71.

[56] Smart N, Rossdeutsch A, Riley PR. Thymosin beta 4 and angiogenesis: modes of action and therapeutic potential. Angiogenesis 2007;10:229-41.

[57] Stevens A, Low J. Human histology. London: Mosby; 1997.

[58] Takeishi T, Hirano K, Kobayashi T, Hasegawa G, Hatakeyama K, Naito M. The role of Kupffer cells in liver regeneration. Arch Histol Cytol 1999;62:413-22.

[59] Van Der Gucht E, Hof PR, Van Brussel L, Burnat K, Arckens L. Neurofilament protein and neuronal activity markers define regional architectonic parcellation in the mouse visual cortex. Cereb Cortex 2007;17:2805-19.

[60] Van Der Gucht E, Vandenbussche E, Orban GA, Vandesande F, Arckens L. A new cat Fos antibody to localize the immediate early gene c-fos in mammalian visual cortex after sensory stimulation. J Histochem Cytochem 2000;48:671-84.

[61] van Furth R, Cohn ZA. The origin and kinetics of mononuclear phagocytes. J Exp Med 1968;128:415-35.

[62] Vartiainen N, Pyykonen I, Hokfelt T, Koistinaho J. Induction of thymosin beta(4) mRNA following focal brain ischemia. Neuroreport 1996;7:1613-6.

[63] Wells CL, Maddaus MA, Simmons RL. Role of the macrophage in the translocation of intestinal bacteria. Arch Surg 1987;122:48-53.

[64] Witmer-Pack MD, Hughes DA, Schuler G, Lawson L, McWilliam A, Inaba K, et al Identification of macrophages and dendritic cells in the osteopetrotic (op/op) mouse. J Cell Sci 1993;104(Pt 4):1021-9.

[65] Xu GJ, Hannappel E, Morgan J, Hempstead J, Horecker BL Synthesis of thymosin beta 4 by peritoneal macrophages and adherent spleen cells. Proc Natl Acad Sci USA 1982;79:4006-9.

[66] Yang H, Cheng X, Yao Q Li J, Ju G. The promotive effects of thymosin beta4 on neuronal survival and neurite outgrowth by upregulating L1 expression. Neurochem Res 2008;33:2269-80.

[67] Yoshida T, Kurella M, Beato F, Min H, Ingelfinger JR, Stears RL, et al. Monitoring changes in gene expression in renal ischemia-reperfusion in the rat. Kidney Int 2002;61:1646-54 